\title{
Points of Discussion and Directions for Research on Caddo Historic Archaeology
}

Timothy K. Perttula

Heritage Research Center, Stephen F. Austin State University

Follow this and additional works at: https://scholarworks.sfasu.edu/ita

Part of the American Material Culture Commons, Archaeological Anthropology Commons, Environmental Studies Commons, Other American Studies Commons, Other Arts and Humanities Commons, Other History of Art, Architecture, and Archaeology Commons, and the United States History Commons

Tell us how this article helped you.

This Article is brought to you for free and open access by the Center for Regional Heritage Research at SFA ScholarWorks. It has been accepted for inclusion in Index of Texas Archaeology: Open Access Gray Literature from the Lone Star State by an authorized editor of SFA ScholarWorks. For more information, please contact cdsscholarworks@sfasu.edu. 
Points of Discussion and Directions for Research on Caddo Historic Archaeology

Creative Commons License

(c) (i) (8)

This work is licensed under a Creative Commons Attribution-NonCommercial 4.0 International License 


\title{
POINTS OF DISCUSSION AND DIRECTIONS FOR RESEARCH ON CADDO HISTORIC ARCHAEOLOGY
}

\author{
Timothy K. Perttula
}

I start with the premise that there are considerable gaps remaining in our basic knowledge of the Caddo historic archaeological record for the period from ca. 1670-1850 in East Texas. The period between ca. A.D. 1542-1670 is better known archaeologically, thanks in large measure to some significant work at Late Caddo sites along the Red River, along Big Cypress Creek, and in the Neches-Angelina River basins, but there are considerable gaps there as well in what we think we know about the life and times of the Caddo in the $16^{\text {th }}$ and $17^{\text {th }}$ centuries, especially on the role Europeans may have played in those early times in effecting the lifeways of Caddo peoples.

How can we make advances in our understanding of Caddo historic archaeology in East Texas? I think there are a number of issues and research problems that can be tackled, and tackled immediately, if we are to make measurable progress in the study of life among the Caddo peoples from the mid- $16^{\text {th }}$ century to the mid- $19^{\text {th }}$ century. I list a few of these below for consideration and discussion:

(a) First, we need to find some common ground in how we go about pursuing good empirical research objectives, such as (1) methods to be employed in actually identifying Caddo historic sites on the ground; (2) adequate characterizations of the stylistic and functional character of historic Caddo material culture; and (3) accurate identifications of the kinds of European trade goods we can expect on Caddo historic archaeological sites;

(a) We should foster a diversity of theoretical and methodological perspectives and approaches; a diversity of approaches to research problems is more likely to produce good results and useful archaeological information, as long as such approaches are made explicit and developed with the full consideration of alternative approaches and perspectives;

(b) Development of more complete and detailed chronologies of the protohistoric and early historic periods, concentrating on more refined ceramic seriations of Caddo vessel and decorated sherd assemblages, and the use of alternative dating methods (TL); also need development of primers and artifact identification handbooks concerning the range of European trade goods found on sites, both in terms of their chronological information (as with glass beads and gun parts) but also with respect to the country of origin of 
such trade goods, and the ways such trade goods may have been manipulated and modified by the Caddo peoples during their subsequent use;

(c) Regional investigations of poorly known areas for information on historic Caddo settlement, as well as a renewed look at those areas thought to be better known (i.e., San Pedro Creek and Nacogdoches area), that may have been occupied during the protohistoric and early historic periods; there are many Caddo villages noted and recorded in historic documents and maps (see Tiller, this volume) that have never been found (in most cases, never looked for) and a concerted effort needs to be made to locate these villages and examine them archaeologically;

(d) Better understand and more fully develop paleoenvironmental and ecological studies during these periods (ca. 1670-1860), so as to more completely view the environmental and climatic context of historic Caddo settlement permanence as seen in the archaeological record, as well as the obvious abandonment of certain areas, and how they may correlate with recognizable periods of climatic stress and likely crop failures;

(e) Need new understandings of changes in subsistence activities through studies of preserved plant and animal remairs from $17^{\text {th }}$ to mid- $19^{\text {th }}$ century Caddo sites; especially the effects of Caddo participation in the deer hide trade (cf. Foster and Cohen 2007);

(f) Document the full range of life ways that probably existed at different social levels in historic Caddo societies; specifically, in addition to the everyday lives of the Caddo peoples, what evidence can we find that will allow us to consider changes and/or statis in the existence and roles of the political and religious elite during these tumultous times;

(g) Better understand economic and stylistic exchanges of products and goods seen in the archaeological record, and clarify the extent and direction of such exchanges between different Caddo groups, between the Caddo and Europeans, and between the Caddo and other groups; and

(h) clarify the character of Caddo ethnic entities (i.e., analogous to affiliated groups and constituent groups in archaeological terms) during this time, and formulate clear methodologies to recognize and study ethnicity in the archaeological record. 
Finally, research needs to be published on Caddo historic archaeological topics and investigations in a timely manner, research needs to be grounded in a good problem with clear objectives, and research needs to be collaborative (e.g., partnering up with the Caddo Nation of Oklahoma and partnering up with archaeological and historical colleagues with similar research agendas and research problems). Underlying all research on the protohistoric and early historic Caddo periods, for me (Perttula 1992), is the idea that it is a study of change in Caddo societies due at least in part to the effects of European contact, the effects of Caddo contact and interaction on European societies, as well as the study of change that is the result of internal evolutionary adaptations by the Caddo peoples themselves.

Let us also not forget that the Caddo historic archaeological record of the postremoval period (after ca. 1840) has been almost completely forgotten/overlooked by archaeologists that work on Caddo archaeological issues/topics, although some historians and geographers have dealt with the period. We should seek out and develop partnerships with historians and geographers (see Tiller, this volume) to make full and comprehensive use of available maps and archival documents that provide locations of historic Caddo villages in East Texas (and Northwest Louisiana), and to use that information to mount concerted archaeological efforts to relocate these villages.

\section{References Cited}

Foster, H. T. and A. D. Cohen

2007 Palynological Evidence of the Effects of the Deerskin Trade on Forest Fires during the Eighteenth Century in Southeastern North America. American Antiquity 72(1):35-51.

Perttula, T. K.

1992 "The Caddo Nation": Archaeological and Eihnohistorical Perspectives. University of Texas Press, Austin. 